\title{
MODERN SYSTEMS OF ORGANIZATION OF DECISIONS ENFORCEMENT AND LEGAL STATUS OF EXECUTORS
}

\author{
Nataliia A. Sergiienko ${ }^{1}$, Solomiia B. Tsebenko², Maryna I. Saienko ${ }^{3}$, \\ Mykola M. Potip ${ }^{4}$, Olena V. Dragan ${ }^{5}$ \\ Department of Public and Private Law, Faculty of Law and International Relations, Borys Grinchenko Kyiv University, Kyiv, \\ Ukraine ${ }^{1}$; Department of Theory and Philosophy of Law, Constitutional and International Law, Institute of Law, Psychology and \\ Innovative Education, Lviv Polytechnic National University, Lviv, Ukraine2; Department of Theory and History of State and \\ Law, Faculty of Training Specialists for Units of Preventive Activity, Dnipropetrovsk State University of Internal Affairs, \\ Dnipro, Ukraine ${ }^{3}$; Department of Law, Faculty of Law and Psychology, Dnipro Humanities University, Dnipro, Ukraine ; De- \\ partment of Theory, History of Law and State and Constitutional Law, University of the State Fiscal Service of Ukraine, Irpin, \\ Ukraine $^{5}$
}

\section{Abstract}

The relevance of the study is as follows: if the substantive decision of a court or other jurisdiction (official) is subject to enforcement, the state must provide an effective mechanism for such kind of enforcement (otherwise, in case of non-compliance with the decision by the obligated person, protection of rights, freedoms, interests of the person will remain only on paper). An important component of such a mechanism is the system of enforcement of decisions. Therefore, each state faces the question of which system of enforcement of decisions to choose, and here we need the experience of other states that have already passed this path and can already clearly understand the results. The purpose of the article is to consider the experience of foreign states in reforming the system of enforcement of decisions and the legal status of executors in order to implement it in Ukraine. Methodological basis of the scientific article is general and special methods of scientific research (deductive, analytical, synthesis method, hermeneutic method, comparative, statistical, historical, dialectical and other methods), which were used to cover the topic of the scientific article. The results of the study contain a generalization of the experience of foreign countries in reforming the system of enforcement of decisions and the legal status of executors. The practical significance of the study is that the scientific article analyzes the application of different systems of organization of enforcement of court decisions, other bodies (officials), different approaches to the legal regulation of the legal status of executors. This can be useful for both legal scholars and legal practitioners, as well as anyone interested in reforming executive legislation.

Keywords: enforcement, enforcement system, organization of enforcement system, executor, enforcement proceedings.

\section{INTRODUCTION}

Scientists and lawyers have been conducting scientific discussions about the systems of organization of enforcement of decisions for many years.
They debated and shared their experiences of which of the systems of such an organization is more effective and acceptable, considering the experience of different states on this matter. 
Nevertheless, this issue remains relevant, although a lot of discussions have already taken place, and the experience of different states has been generalized, and new reforms in this area are being implemented. It seems to us that the current situation is directly related to the dynamics of the state protection of the rights, freedoms and interests of individuals. In particular, if at the initial stages of reforming the system of enforcement of decisions the issue of effective enforcement is acute (effective means increasing the percentage of executed decisions), in the future, completely different issues may come to the fore, such as balancing the rights and interests of the parties; the adequacy of the cost of enforcement (both for the state, as the organizer of the enforcement system, and for the debtor as the person from whom a judgment debt is collected); the legal status of the executor (especially given that he is empowered to apply coercive measures).

Of course, it is possible to object to the above thesis that the formation/reformation of the enforcement system considers all of the above, however, everything can be taken into account at once only on paper, and the implementation practice will show the vectors of the improvement of the implemented system. That is why the communication between the state (in particular, as represented by the institution that develops and is responsible for the implementation of the reforms and enforcement of decisions) and the subjects who closely feel the impact of the system - whose rights, freedoms, responsibilities it affects (here we can talk about the executors, the parties to the enforcement proceedings and other subjects of the enforcement process); analysis of the results of the introduced changes; forecasting the dynamics of development of the system of organization of enforcement of decisions.

In this scientific article the analysis of modern systems of the organization of enforcement of decisions and the legal status of executors through a prism of experience of different states is carried out. The main focus is on enforcement systems and the legal status of enforcement agents in
France, Estonia, Lithuania, Sweden, Finland, Bulgaria, and Georgia /1/. The selection of states with different legal systems and different legal traditions is not accidental, it is done to show that there is no universal system of enforcement of decisions, so it is worth a prudent approach to reforming such a system. And for this, it is important to consider foreign experiences - different foreign experiences. Therefore, the attention should be paid to the experience of Western European and post-Soviet states that can already present the results of reforming the sphere of enforcement of decisions. In order to make fewer mistakes when reforming the enforcement system in Ukraine, we should take into account the experience of foreign courtiers. First of all, it is important to analyze the said experience and relevant scientific concepts to have a thorough understanding of certain processes in reforming the organization of enforcement of decisions, because the effectiveness of practice directly depends on the soundness of the theory that underlies it. Thus, the main question of our study is to define what kind of foreign experience Ukraine should adopt to reform the system of enforcement of decisions. Given the logic of the research process, it seems appropriate to first address a more general issue - the problem of modern enforcement systems, paying attention to the countries that have chosen a certain system, and then to move on to analyze the legal status of executors in different states.

\section{MATERIALS AND METHODS}

The methodology of this scientific article is based on the adoption of various methods of scientific knowledge. The deductive method of scientific cognition allowed us to build the logic of research and presentation of scientific material. Thus, firstly, the scientific article analyzes the issues of modern systems of enforcement of decisions (more general issue), and then reveals the issue of the legal status of executors in different states (narrower issue). The analytical method of scientific research has been used in the consideration of modern systems of organization of enforcement of decisions. In particular, the most common in modern jurisprudence classifications of 
enforcement systems and he experience of reforming enforcement systems in different countries and its results have been analyzed. Using this method, the powers of performers in different states have been studied.

The method of synthesis has been used in the formation of intermediate and final conclusions of the scientific article. The hermeneutic method of scientific knowledge enabled us to conduct research of scientific texts, which covered the issues of enforcement systems in different states, the legal status of executors, and the texts of regulations of different states, the rules of which regulate the above issues. For example, using the hermeneutic method of scientific knowledge, the text of the Law of Georgia "On Enforcement Proceedings" of April 16, 1999 /2/ has been studied.

The adoption of the comparative method of scientific research permeates the entire article, as the subject and purpose of the article relate to the experience of foreign countries in reforming the system of enforcement of decisions and the legal status of executors. Therefore, the article compares the systems of enforcement of decisions and the legal status of executors in different countries, the dynamics of changes in such systems.

The statistical method as a method of scientific knowledge allowed us to demonstrate the efficiency of enforcement of decisions in the state executive service and in the private system of enforcement (private executors) in Ukraine. The historical method of scientific knowledge has been used to give an overview of the history of reforming the enforcement systems in foreign countries (Lithuania, Estonia, France, Georgia) and to provide background for analyzing the state of the system of decision enforcement before implementing the reforms and after. The dialectical method of scientific knowledge allowed us to study some aspects of the experience of foreign states in the field of reforming the enforcement system in terms of how the trends change - Estonia is a clear example of the said changes. In this country, the enforcement reform functions according to the 'pendulum' principle, which means that the process of reforming the enforcement system returns to the point where it is necessary to re-implement certain aspects of the previous organization of enforcement of decisions. The application of the appropriate methodology in the scientific article allowed us to conduct a full-fledged scientific research of the topic within the framework that can be carried out in the scientific article, to achieve the goal stated for this article.

\section{RESULTS AND DISCUSSION Modern systems of organization of decisions enforcement}

It seems that there are many criteria for classifying enforcement systems. For example, V.V. Yarkov /3/ notes that there are two main classifications of global enforcement systems. He immediately emphasizes that these author's classifications, like all others, are not completely legally correct, at the same time, allow a better understanding of the content of a particular system of enforcement proceedings to exist in a particular country. This scholar was the first to classify enforcement systems according to the method of organizing the profession. The first classification is based on the method of organizing the profession of bailiff (bailiff, huissiers de justice - there are many name variations), as well as opportunities and limits of participation of non-governmental organizations in enforcement proceedings.

Historically, several basic models of enforcement proceedings have been developed according to this criterion: public law, private law (nonbudget) and mixed model - public law with the admission of varying degrees of private law initiative. The following classification of the enforcement systems provides V.V. Yarkov - a classification of enforcement systems according to the type of bodies and officials. The second classification is based on the place of law enforcement agencies and officials - they most often work either within the judiciary, being court officials, or the executive, usually judicial bodies. 
The classification of modern enforcement systems is presented quite accurately and concisely by $\mathrm{O}$. Tkachuk /4/. This scholar-lawyer notes that depending on whether the enforcement bodies are a single system in the state, which is centralized vertically, or the existence of several independent bodies, there are centralized and decentralized enforcement systems. The essence of the centralized system is that the enforcement is carried out by one of the homogeneous bodies of enforcement of decisions, which, however, can belong to the executive branch and be administered by the courts or operate on a private basis. Decentralized systems, on the other hand, are characterized by discretion, which manifests itself in the fact that different enforcement agencies carry out different enforcement actions. The proposed classification criterion is based on the European Commission on the Efficiency of Justice (CEPEJ). In one of the latest studies, the commission provided two categories of countries:

- with centralized enforcement systems, where a single body operates regardless of the type of enforcement action and the area in which enforcement is carried out (Austria, Belgium, Spain, Finland, the Netherlands, Romania, Sweden and, to a large extent, France);

- with decentralized enforcement systems, where enforcement functions can be distributed between different bodies depending on what actions need to be taken.

Sometimes the system of enforcement of decisions, which is represented by different - public and private subjects of enforcement is called mixed. Mixed systems of enforcement of court decisions are characterized by the transfer of only a certain part of the functions of enforcement of court decisions from the state to private organizations $/ 5 /$.

If we take the given classifications of enforcement systems as a basis, it should be noted that currently in Ukraine, there is a decentralized enforcement system, because the enforcement is carried out by state executors who hold positions in the state executive service, which is part of the Ministry Justice of Ukraine, and private executors who are subjects of independent professional activity; the enforcement system in Ukraine is currently mixed; by the criterion of the type of bodies and officials of enforcement, it should be noted that state executors are civil servants in the system of executive bodies (given the legal status of state executive services), and private executors are subjects of independent professional activity (respectively, are not representatives of any branch of government).

Regarding the state of efficiency of the enforcement of decisions in Ukraine, the statistics are as follows: according to the Ministry of Justice of Ukraine, in 2019 there was UAH 796.8 billion to be enforced, while only UAH 20.7 billion was collected in the same period. The total amount of unpaid debts according to court decisions in 2019 is more than a quarter of Ukraine's GDP. It also indicates that the enforcement rate does not exceed $2.6 \%$ per year. More than half of the above-mentioned debt according to court decisions in the amount of UAH 796.8 billion refers to state bodies, including state enterprises. Since the start of their activity in 2017, private executors have demonstrated significant results. These official statistics show that the performance of private executors in terms of the amount of debt collected is 5 times better than the results of the State Enforcement Service. For comparison, in 2019, 230 existing private executors collected UAH 4.2 billion, while 4,472 state executors subordinated to the Ministry of Justice collected UAH 16.5 billion during the same reporting period /6/. Such figures in the results of enforcement by public and private enforcement agents are impressive, and raise a relevant question: perhaps it would have been better to introduce a system of enforcement of decisions by private enforcement agents from the beginning, and since it has not been done before, it would make sense to implement it now. Particularly relevant is the second part of the above (arbitrary introduction of a private enforcement system now) - we use this as a working hypothesis 
and analyze the experience of foreign countries that have already reformed the enforcement system by using private enforcement to have sound arguments to confirm or refute the hypothesis.

It is difficult to answer unequivocally why the reform of the enforcement system in Ukraine did not result in the immediate introduction of private (so that the enforcement is carried out by private executors) centralized (meaning that private executors as the subjects of enforcement to be entrusted with the enforcement of decisions) enforcement system. Even before the introduction of the institution of private performers in the legal community, there were statements about the inexpediency of drastic reformation. In particular, although the private enforcement service is more efficient, as the private enforcement agent has a financial interest in the prompt execution of the decision, it is considered more acceptable for post-Soviet states to introduce a mixed system, as citizens are accustomed to the state protection of their rights $/ 7 /$.

It seems that the way the Soviet past is mentioned here, sounds hardly relevant: the past is what it is, and the experience of Lithuania (which also was a part of Soviet Union) shows that it is possible to reform the enforcement system quickly and effectively. According to A.S. Kuzmina with reference to P. Salatny, instead of civil servants, private bailiffs work in Lithuania, the appearance of which was caused by the low level of the work efficiency of state executors /8/. Prior to the reform in Lithuania, each district court had one bailiff's office, which employed from 2 to 36 bailiffs.

A total of 338 state bailiffs worked in Lithuania before the reform. The reasons for reforming the enforcement system in Lithuania are the inability to implement many provisions of the law that reflect the current state of affairs in society, outdated regulation of the status of a court enforcer, low efficiency of enforcement of court decisions, the desire to save budget funds /9/. On January 1, 2003, the Law of the Republic of Lithuania "On
Bailiffs" entered into force. A.O. Fokina /10/ notes, referring to the Chambers bailiffs Lithuania, according to statistics today in Lithuania enforcement activities carried out 118 police officers in including. 101 bailiffs' offices and 32 offices. At the beginning of 2013, there were 97 bailiff offices in Lithuania, with a total of 117 bailiffs (30 of them in Vilnius) and 262 assistant bailiffs /11/. According to the Lithuanian Bailiffs Chamber, there are currently 96 bailiffs offices throughout Lithuania, in which 114 bailiffs operate /12/.

Lithuania is not the only country that has been able to effectively reform the enforcement system. In particular, such a reform took place in Estonia in 2001. On March 1, 2001, the Law on Bailiffs came into force in Estonia. The law regulates the execution of decisions by private bailiffs. Until now, decisions have been enforced by bailiffs who were civil servants. According to the new ideology, all costs associated with the execution are borne by the debtor. Freelance bailiffs are the only institution that has the right to enforce decisions /13/. Since 2001, the profession of bailiff has been a free profession, i.e. a bailiff is neither an entrepreneur nor a government official $/ \mathbf{1 4} /$. Since 2010, the Estonian Chamber enforcement and bankruptcy managers function in Estonia /15/. The experience of Lithuania and Estonia shows that even a "drastic" enforcement reform (immediate transition to a private enforcement model) can be acceptable when it comes to a real intention to increase the effectiveness of enforcement of courts and other bodies (officials) decisions.

A. Uzelach focused the attention on the aspect of the private model of enforcement of decisions: he proposed an interesting wording "experience of privatization of law enforcement agencies in the regions" while providing an interesting question: "Why privatization in the conditions of the reform has become almost a bestseller despite numerous alternatives in the public sector?". The response summarized that there was no systematic research that could answer these questions, but some of the possible factors could be identified. Some of them are of a general political nature and 
may be due to the fact that in the old days, private professions were suppressed, which led to the opposite trend in favor of a new paradigm of market economy and liberal capitalism (sometimes it is identified with the idea of outsourcing various government functions).

On the other hand, the existing structures of state bodies were often weak and unstable. In the new environment, in which their functions are becoming increasingly important, they were even less able to perform their tasks effectively /16/. It seems that the root of choosing a private model of enforcement of decisions is the inefficiency of state institutions in enforcing decisions. But how drastically we should change the system of enforcement of decisions (to move to a private or mixed system of enforcement of decisions) - this is the question that must be answered by each state individually, because it is the state who must ensure the rights, freedoms, interests of individuals, and the enforcement of decisions. After all, it is with the execution of a court decision or another body (official) that the rights, freedoms, and interests of individuals are actually being restored. And it is up to the state to develop and implement a mechanism for such renewal: both institutional (which institutions will carry out such renewal) and procedural (in what way, i.e., in what procedural form, the enforcement of decisions will be conducted).

V.V. Yarkov, answering the question posed to him - which system is more rational and profitable - says that he thinks that the non-budget system is ultimately more effective because it solves one of the main issues that hinders the effective work of the bailiff - their financial interest in the results of work /17/. It is worth agreeing with the above statements, because in fact, having the appropriate financial incentives, a person will obviously work more efficiently, which will directly have an impact on the results of their work.

It is impossible to say that it is enough to reform the enforcement system once and the effectiveness of the enforcement will be achieved. For example, in Estonia, which is often cited as an example of successful enforcement, the issue of "expensive" enforcement in some categories of cases have already been raised. For example, the Minister of Justice of Estonia in 2019 noted that “... today, enforcement proceedings are too expensive for people. For example, in the case of a fine of 50 euros, bailiffs must be paid at least 66 euros, which is significantly more than the amount of the fine itself. We want enforcement proceedings to be more accessible to the people, and for the main amount to be used to pay real debt, not to pay for the services of executors. According to preliminary estimates, in the future, the executive fee at the request of the state will be reduced by almost 10 times.

We will also review the amount of fees for bailiff services $/ \mathbf{1 8} /$. This comment was made by the Estonian Minister of Justice in the context of the proposal of the Estonian Ministry of Justice and the Estonian Ministry of Finance to transfer the enforcement of state and local property claims to the Tax and Customs Department and for bailiffs to focus on private claims requiring their professional knowledge. The organization of the sale of debtors' property in the enforcement cases of the Tax and Customs Department /19/ was also in the powers of the bailiffs. V.V. Yarkov drew attention to the possibility of such problems in one of his scientific articles in 2006. In particular, the scholar noted that the non-budgetary system of enforcement is more effective, but in the transition to this system, there are a number of problems, among which V.V. Yarkov singled out the regulation of tariffs for enforcement actions and other work performed by the bailiff; the interest of the nonbudget bailiff in the execution of penalties for small amounts, such as alimony, fines, etc., because here the execution may be time consuming, and not profitable $/ \mathbf{2 0} /$.

The issue of the enforcement fee is acute in its implementation by a private entity: on the one hand, the executor should be profitable to work at the appropriate rate, and on the other hand, the amount of the enforcement fee should not be 
disproportionately burdensome for the debtor. And this is an illustrative example if you need to collect a small amount of money from the debtor (this is exactly the situation that Estonia faced): the amount of recovery is small, and the amount of enforcement action to ensure such recovery may be significant, so if the contractor's wage will be small, they will not be interested in such work, and if we talk about a higher rate - it will be disproportionate to the amount of the penalty. It seems that a universal "recipe" for a way out of this situation can hardly be found. In particular, at the IV International scientific and practical conference "Actual problems of the executive process: theory and practice" /21/, which was attended by one of the co-authors of this scientific article, there was a discussion of the feasibility of absolutely all types of penalties in Ukraine (including small fines) that could be carried out by both public and private executors.

In the context of the discussion on this issue, one of the private performers expressed the opinion that they would be glad if private performers could conduct enforcement proceedings to collect all types of fines (including small fines), provided that the state guarantees a fixed amount of remuneration to the private performer. This seems to be an interesting idea to address the effectiveness of the enforcement of small sums (in particular, fines for traffic violations, etc.) and the fairness of the tariff for the recovery of such amounts, it seems that the state should decide on the basic concept of recovery: is it an inevitable punishment for the violator, and therefore the state is willing to pay for the work of a private performer even if their remuneration is greater than the budget revenue from the collection of such a fine, etc.) or should the collection of such small amounts still be economically feasible. It is hardly possible to reach a consensus on the amount of remuneration of a private executor - so that they are interested in the enforcement of decisions involving the recovery of small amounts. Another interesting idea to address this issue is given by V.V. Yarkov: in this regard, we should consider the experience of the notary system where unreceived tariffs have been included in the notary's expenses until recently. It reduced taxable income and thus encouraged the notary to perform notarial acts free of charge for the applicant $/ 22 /$.

The example of Estonia is truly illustrative. It clearly demonstrates that:

1) even a clear embedding of a certain "ideology" in the reform of enforcement of decisions (as noted by S. Shandruk /23/, this ideology "all costs associated with the execution is borne by the debtor" - this was stated above) will not guarantee the consistency of the introduced systems;

2) any reform, even successful in general, requires adjustment considering the requirements of the time, balancing the interests of the parties to the enforcement proceedings;

3) the need for such an adjustment may lead to proposals even to change the institutional support of enforcement (in the case of Estonia - this is a proposal to transfer to the Tax and Customs Enforcement of decisions in some categories of cases - i.e., essentially "reverse" from private enforcement to public execution in some categories of decisions).

Thus, the passage of time and changing circumstances, the identification of shortcomings in the functioning of the relevant system should be factors in reviewing the existing legal regulation of the organization and the implementation of enforcement decisions.

In view of the above, our working hypothesis about the expediency of applying a completely private system of enforcement of decisions in Ukraine now as a factor of improving the efficiency of enforcement of decisions can only be partially confirmed. In particular, enforcement of decisions by private executors may increase the percentage of enforced decisions, but this may lead to new tasks that will inevitably have to be solved, such as remuneration to private executors, etc., which are to be recovered from debtors. 
And the state will not be able to avoid solving such problems, because according to Art. 1 of the Constitution of Ukraine, Ukraine is a social, legal state. Accordingly, the state must take into account the rights, freedoms, interests of various subjects of legal relations, including debtors in court and other decisions that are subject to enforcement. Therefore, if a private enforcement system is introduced, a mechanism for balancing the rights, freedoms, interests of all participants in enforcement proceedings, other entities whose rights, freedoms and interests may be influenced by such an enforcement reform, should be introduced at the same time.

\section{Legal status of executors of decisions in differ- ent states}

It would be premature to talk about different systems of enforcement of decisions without touching on the legal status of executors, because it is the executor who takes action to directly enforce decisions, and to a large extent the most effective exercise of its powers results in timely, complete and impartial enforcement.

A typical private law enforcement model, which was later borrowed by other countries, was implemented in France. Bailiffs in this country act as the main subjects of enforcement proceedings, endowed with power. If necessary, the bailiff has the right to involve representatives of law enforcement agencies in enforcement actions. French bailiffs, like entrepreneurs, can hire technical staff on their own. Often the profession of bailiff is family in nature, when relatives work as bailiffs in the same office. The bailiff also has the right to choose a successor /24/. In France, the activity of the performer is not just a legal activity, but an honorable work, which is engaged in for generations. In France, a system of private enforcement has historically developed, where the powers of bailiffs are not performed by civil servants, but by people who have received a license from the state for this type of activity and carry it out independently.
The profession of bailiff was regulated by various royal ordinances, which were adopted in 1556, 1667, and in 1813 under Emperor Napoleon I. Today, the legal status of bailiff is determined by the Ordinance of November 2, 1945, and the Code of Civil Procedure of France in 1806. Some changes in the system of enforcement proceedings in France took place in 1992 /25/. S. Shandruk gives similar formulations, pointing out that in France, bailiffs are not civil servants, they act on the basis of a state license as private entrepreneurs. Their legal status is determined by the Ordinance of November 2, 1945 (with subsequent changes from 1992). A bailiff in France is an official because they receive powers from the state, but they belong to the free (liberal) professions /26/. The legal status of the French bailiff as the freedom of the bailiff's profession (although they do not belong to private lawyers) and obtaining authority to implement them from the state are the symbiosis that we should pay the attention to. Here, it is quite logical what Kolobov L. draws attention to the fact that the bailiff has no right to choose clients (because they do not belong to private lawyers).

It is very interesting that a French executor, not only the executor of a court decision or a decision of another body (official). Their powers include, in particular, the service of documents. Thus, L. Kolobov reasonably notes that the powers of the enforcement agent in France include the following: service of summonses; execution of court decisions on behalf of the state, also resorting to the application of measures of state (administrative) coercion; drafting documents, protocols that have the value of evidence, providing legal advice and other actions $/ 27 /$. They participate in court hearings where they ensure the maintenance of order, can provide legal advice $/ \mathbf{2 8} /$.

It should be noted that the powers of the French bailiff do not cover the enforcement of judgments in favor of the state. If it is necessary to enforce a court decision in favor of the French Republic, it is within the competence of the state treasury. In this context, it is worth agreeing with V.V. Yarkov, who notes the general feature of the 
competence of bailiffs in France. This scholar notes that the French legal system is based on the division of positive law into private and public. Accordingly, the judicial organization differs in the allocation of courts for civil and criminal cases, as well as judges of administrative justice, which are combined into various systems. Therefore, the bailiff does not enforce decisions in favor of the state and in general acts adopted by administrative courts. For these purposes, there is a special system of bailiffs of the state treasury who are civil servants $/ 29 /$. Thus, it is really worth agreeing with the statement that France is a typical representative of the private law model $/ \mathbf{3 0} /$, but with the caveat that in the French Republic, there is a differentiation of enforcement depending on the scope of legal relations, decisions on which should be enforced. (Execution of decisions in the field of public law relations, in particular, decisions in favor of the state does not belong to the powers of bailiffs as free professionals).

The French model of enforcement was taken as a basis for reforming the relevant system in Estonia. In Estonia, enforcement proceedings are carried out by an organizationally separate enforcement body - a bailiff who is a freelancer. In the context of the legal status of a bailiff in Estonia, it is very interesting to differentiate their powers - among them those that they must exercise as a state authorized to enforce decisions, and those that they have the right to exercise at its discretion. The Chamber of Bailiffs and Bankruptcy Trustees articulates this in its materials: the bailiff's official activity is divided into official actions, the performance of which is obligatory for the bailiff (conducting enforcement proceedings on the basis of the code, delivery of documents in accordance with court documents, inventory inheritance and management of inherited property on the basis of the Law "On Inheritance", in cases provided by law - conducting auctions at the request of the court or administrative body for enforcement proceedings), and official actions, the performance of which is voluntary (private auction, legal advice and drafting a legal document, delivery of the document) $/ 31 /$.
In Lithuania, according to the Law on Bailiffs, a bailiff is a person authorized by the state to be entrusted with the functions of executing executive documents, establishing factual circumstances, transferring documents, as well as other functions established by law. The bailiff may also deliver the services provided for in this Law, provided that this does not interfere with the bailiff's functions /32/. The bailiff may deliver the following services provided for in this Law: state the factual circumstances; transfer and hand over documents; to store (administer) property in the process of execution; advise on legal issues; to sell movable and immovable property by auction; to mediate in the performance of property obligations; provide bankruptcy administration services; provide mediation services in resolving disputes; to serve international judicial and non-judicial documents. As can be seen from the above, the powers of the Lithuanian bailiff are very broad and diverse, and in addition to the actual "executive" powers (i.e., those directly related to enforcement), he can provide a number of services that can be as related and not directly related to the enforcement of the decision. The Law on Bailiffs divides all activities of a bailiff into two categories: the functions of a bailiff and the services provided by him. This division is important. The bailiff has no right to refuse a person who has applied to perform the functions of a bailiff /33/. This is very important for understanding the essence of the legal status of a bailiff in Lithuania: yes, they are freelance professionals, however, having received the authority from the state to enforce decisions, they must implement them.

In some states, there is a comprehensive enforcement system in which a single enforcement body recovers funds from the debtor's assets. The most typical example is Sweden (a similar model has also been adopted in Finland), where the National Executive Agency enforces judicial, administrative and other decisions /34/. According to the criterion of which bodies are empowered to enforce decisions, the Swedish system of enforcement of decisions (SED) is attributed to Yu.M. Yurkevych, O.B. Verba-Sydor, N.M. Hrabar and some other 
scholars of administrative SED. These legal scholars note that the countries where such a SED is applicable, are Sweden, Finland, Russia. In such SED, enforcement of decisions is carried out by administrative bodies independent of the court. In Sweden, it is a public authority under the Ministry of Finance /35/. Finland has introduced a system of enforcement of decisions, according to which the competence to enforce decisions belongs to the executive body - the State Enforcement Service. According to P.V. Makushev with reference to S.V. Sazanov, the Finnish enforcement system includes the Ministry of Justice, the head of the provincial government and local enforcement units. The Ministry and the Head of the Provincial Board are the governing bodies. The actual enforcement proceedings are carried out by local units headed by the county vogt $/ 36 /$.

In the Republic of Bulgaria, since 2005 there is a mixed system of enforcement of decisions - these are state bailiffs, whose activities are regulated by the Law of the Republic of Bulgaria "On the Judiciary", in particular, its Art. 264, and private bailiffs, whose activities are provided by a separate Law "On private bailiffs". According to the current legislation of Bulgaria, public and private executors can perform cases of the same categories $/ 37 /$.

A mixed system of enforcement of decisions also exists in Georgia, it is represented by the fact that enforcement is carried out by the National Enforcement Bureau and private enforcement agents. Such a structure of enforcement bodies is provided by Art. 3 of the Law of Georgia "On Enforcement Proceedings" of 16.04.1999. The National Executive Bureau is a legal entity under public law, which is within the scope of management of the Ministry of Justice of Georgia. Decisions to be enforced in accordance with Art. 2 of this Law, on behalf of the National Bureau directly executed by the executors of the Executive Bureau on the basis of the order of the Chairman of the National Executive Bureau, as well as persons employed in the National Executive Bureau and trainees of the National Bureau (hereinafter- executors) (see Articles 3-4 of the Law Georgia "on enforcement proceedings" from 16.04.1999 /38/.

The structure of the National Enforcement Bureau includes services /39/, each of which has the appropriate competence. Remarkably, the structure of the present National Bureau of Police (Police Executive Management) (the Law of Georgia "On Enforcement Proceedings", 1999). In Georgia, a private contractor - a natural person who performs public authority to executive activities on the whole territory of Georgia under license from the executive activity, issued by the National Executive Bureau (the Law of Georgia "On Enforcement Proceedings", 1999). Thus, in Georgia, a private executor, although exercising public authority - the enforcement of court decisions, other bodies (officials), but by its legal status is a private entity. Interestingly, they have the right and also provide legal advice on implementation and advisory activities covered by this concept of executive activities (see. Ch. 4 Art. 14-6 of the Law of Georgia "On Enforcement Proceedings"/40/. In the context of borrowing the experience of foreign countries in terms of legal regulation of the legal status of the executor, firstly, it is necessary to determine the system of organization of enforcement of decisions - which one it should be - private, state, mixed. This is the turning point when we talk about borrowing such an experience.Questions about the systems of organization of enforcement of decisions, the legal status of executors were the subject of scientific interest of V.V. Yarkov /41/, O. Tkachuk /42/, L. Kolobov /43/, S. Shandruk /44/, O.B. Verba-Sidor /45/, and other legal scholars /46, 47/. But given the scope of the subject and its issues, it is unlikely that this topic can be considered fully and comprehensively studied.

\section{CONCLUSION AND RECOMMENDATIONS}

To conclude, it is necessary to generalize the following: among a variety of systems of the organization of enforcement of decisions, there is no 
expediency to speak about which of them is more effective. The experience of different countries shows that in this perspective it is worth talking about acceptability and relevance of the appropriate system of organization of enforcement of decisions for a particular state (considering its legal traditions, the level of development of civil society, the mechanism of the state, the legal system, etc.). But even taking into account all these factors will not guarantee the construction of a constant effective model of enforcement when reforming the system of enforcement of decisions. And the above example of Estonia confirms this - the implemented model of enforcement organization, in general, can be assessed as acceptable and relevant, but time has shown some shortcomings in its functioning, so there is a reason for reflection and action to improve the system of enforcement of decisions. Therefore, adopting the positive experience of foreign countries, Ukraine, in particular, should approach this carefully: if such experience has shown effectiveness, in general, but later revealed significant nuances that needed crucial refinement, it is advisable to immediately consider such nuances (before implementation). In particular, it seems appropriate that if, after all, Ukraine plans to introduce a private system of enforcement, a mechanism for balancing the rights, freedoms, interests of various participants in enforcement proceedings, individuals whose rights, freedoms, interests that may be influenced by such a reform, should be implemented as well.

One more thing that has shown us the experience of foreign countries in reforming the system of enforcement of decisions: the effectiveness of enforcement was achieved by the fact that such a reform did take place - there were not only the relevant regulations that changed the organization of the system enforcement of decisions, but also their instructions were implemented. And let time show that there are still ways to improve the reformed areas, but there are no limits to perfection, and only the one who goes will master the path. The results of this research will be useful for both legal scholars and legal practitioners, in particular those interested in enforcement of decisions, reforming this area and applying the experience of foreign countries. This research may also be of interest to those involved in the development of the enforcement reforms in Ukraine.

Notes

/1/ Ministry of Justice of Georgia. (2020), National Bureau of Enforcement. Retrieved from: http://nbe.gov.ge/index.php?lang_id=RUS\&sec_id=32\&info_id=8545

/2/ Parliament of Georgia. (1999), Law of Georgia “On Enforcement Proceedings". Retrieved from https://matsne.gov.ge/ru/document/view/18442?publication=99

/3/ Yarkov, V.V. (2006), The main world systems of enforcement. University Scientific Notes, 2(18), 84-101.

/4/ Tkachuk, O. (2016), Reforms on samples. What models of execution of court decisions are used in European countries and what changes should Ukraine move towards. Law and Business, 37(1283). Retrieved from: https://zib.com.ua/ua/125519yaki_modeli_vikonannya_sudovih_rishen_vikoristovuyut_u_krain.html

/5/ Kolobov, L. (2017), Comparative analysis of enforcement proceedings in leading foreign countries. Jurnalul Juridic Național: Teorie Și Practică, 6, 86-89.

/6/ New Justice. (2020), Why does Ukraine need new legislation in the sphere of compulsory execution of decisions? Retrieved from https://newjustice.org.ua/uk/novini/navishho-ukrayini-potribnenove-zakonodavstvo-shhodo-vikonannya-rishen/

/7/ Verba-Sidor, O.B. (2015), Reforming the system of execution of decisions of jurisdictional bodies of Ukraine. University Scientific Notes, 1(53), 38-45.

/8/ Kuzmina, I.S. (2015), Foreign experience in building executive systems: comparative characteristics and prospects of application in Ukraine. Bulletin of $\mathrm{Za}$ porizhia National University, 1(2), 139-145.

/9/ Balsiene, J., Meilus, K., Tamošuniene, E., \& Višinskis, V. (2013), Reform of the executive production system in Lithuania. Bulletin of the BSU, 3(1), 79-83.

/10/ Fokina, A. O. (2019), Improvement of the stage of execution of court decisions in national law enforcement practice and European countries. Journal of Kyiv University of Law, 3, 283-288.

/11/ op. cit. in /9/

/12/ Lietuvos Antstolių Rūmai. (2021), Lithuanian Bailiffs Chamber. Retrieved from 


\section{https://www.antstoliurumai.lt/ru/lietuvos- antstoliu-rumai}

/13/ Shandruk, S. (2010), Systems of enforcement of court decisions. World experience. Democratic Governance, 5. Retrieved from http://lvivacademy.com/vidavnitstvo_1/visnik5/fail/+Shandruk.pdf

/14/ op. cit. in /9/

/15/ The Estonian Chamber of Bailiffs and Trustees in Bankruptcy. (2021), Retrieved from https://kpkoda.ee/en/chamber/

/16/ Uzelach, A. (2011), Privatization of enforcement bodies - a step forward for transition countries? In Enforcement and Enforceability: Traditions and Reforms. Moscow, Berlin: Infotropic Media.

/17/ op. cit. in /3/

/18/ Justiitsministeerium. (2019), Unpaid fines will be collected by the Tax and Customs Department. Retrieved from https://www.just.ee/ru/novosti/neoplachennyeshtrafy-budut-vzimatsya-nalogovo-tamozhennym-departamentom

/19/ Justiitsministeerium. (2019), Reorganization of the executive system. Retrieved from: https://www.just.ee/ru/reorganizaciyaispolnitelnoy-sistemy

/20/ op. cit. in /3/

/21/ Fursa, S. (2019), IV international scientific and practical conference "Current Problems of the Executive Process: Theory and Practice". Kyiv: Taras Shevchenko National University of Kyiv.

/22/ op. cit. in /3/

/23/ op. cit. in /13/

/24/ Galperin, M.L. (2017), Executive production: a textbook for bachelor's and master's degrees. Moscow: Urayt.

/25/ op. cit. in /3/

/26/ op. cit. in /13/

/27/ op. cit. in /5/

/28/ op. cit. in /13/

/29/ op. cit. in /3/

/30/ Grishko, E.M. (2016), Public administration in the field of enforcement of decisions of courts and other bodies in Ukraine. Kyiv: National Academy of Public Administration under the President of Ukraine.

/31/ Pool, Ja. (2017), Review of the legal order of enforcement proceedings in Estonia. Chamber of bailiffs and trustees in bankruptcy. Retrieved from http://www.juristideliit.ee/wp-content/uploads/2017/04/Koja+ja+TM+esitlus+120317.pdf

/32/ op. cit. in /9/

/33/ op. cit. in /12/

/34/ op. cit. in /24/

135/ Yurkevych, Yu.M., Verba-Sydor, O.B., Hrabar, N.M., Dutko, A.O., \& Vorobel, U.B. (2020), Enforcement proceedings: textbook (in diagrams and tables). Lviv: Lviv State University of Internal Affairs.

/36/ Makushev, P.V. (2017), State Executive Service in Ukraine: administrative and legal research. Zaporizhzhya: Zaporizhzhya National University.

/37/ Belikova, S., \& Popova, V. (2017), Enforcement: comparative legal analysis of the legislation of Ukraine and Bulgaria. Bulletin of the National Academy of Prosecutors of Ukraine, 4(50), 104-110.

/38/ op. cit. in /2/

/39/ Ministry of Justice of Georgia. (2010), National Execution Bureau of Georgia. Retrieved from http://nbe.gov.ge/in-

dex.php?lang_id=RUS\&sec_id=25

/40/ op. cit. in /2/

/41/ op. cit. in /3/

/42/ op. cit. in /4/

/43/ op. cit. in /5/

/44/ op. cit. in /13/

/45/ op. cit. in /7/

/46/ Reznik, O., Getmanets, O., Kovalchuk, A., Nastyuk, V., \& Andriichenko, N. (2020), Financial security of the state. Journal of Security and Sustainability Issues, 9(3), 843-852

/47/ Yaroshenko, O. M., Vapnyarchuk, N. M., Lozovoi, S. V., Yakovleva, G. O., \& Yakovlyev, O. A. (2018), General-compulsory medical insurance: World experience. Journal of Advanced Research in Law and Economics, 9(5), 1829-1838. 